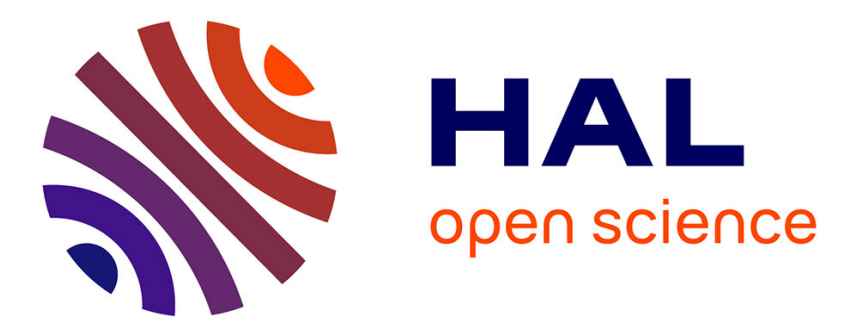

\title{
Detailed structural elucidation of different lignocellulosic biomass types using optimized temperature and time profiles in fractionated Py-GC/MS
}

Maria Gonzalez Martinez, T. Ohra-Aho, T. Tamminen, D. da Silva Perez, M. Campargue, C. Dupont

\section{To cite this version:}

Maria Gonzalez Martinez, T. Ohra-Aho, T. Tamminen, D. da Silva Perez, M. Campargue, et al.. Detailed structural elucidation of different lignocellulosic biomass types using optimized temperature and time profiles in fractionated Py-GC/MS. Journal of Analytical and Applied Pyrolysis, 2019, 140, pp.112 - 124. 10.1016/j.jaap.2019.02.011 . hal-03484969

\section{HAL Id: hal-03484969 \\ https://hal.science/hal-03484969}

Submitted on 20 Dec 2021

HAL is a multi-disciplinary open access archive for the deposit and dissemination of scientific research documents, whether they are published or not. The documents may come from teaching and research institutions in France or abroad, or from public or private research centers.
L'archive ouverte pluridisciplinaire HAL, est destinée au dépôt et à la diffusion de documents scientifiques de niveau recherche, publiés ou non, émanant des établissements d'enseignement et de recherche français ou étrangers, des laboratoires publics ou privés.

\section{(ㄷ)(1) $\$$}

Distributed under a Creative Commons Attribution - NonCommerciall 4.0 International 


\section{Detailed structural elucidation of different lignocellulosic biomass types using} optimized temperature and time profiles in fractionated Py-GC/MS

M. González Martínezza,b,c,, T. Ohra-ahod, T. Tamminen ${ }^{d}$, D. da Silva Pereze , M. Camparguef, C. Dupont ${ }^{g}$

a Université Grenoble Alpes, CEA, Laboratoire de Préparation des Bioressources (LPB), F-38000 Grenoble,

5 France

6 b Université de Toulouse; INPT, UPS; Laboratoire de Génie Chimique, 4 Allée Emile Monso, F-31030

7 Toulouse, France

8 c CNRS; Laboratoire de Génie Chimique; F-31030 Toulouse, France

9 d VTTTechnical Research Centre of Finland Ltd, P.O. Box 1000, FI-02044 VTT, Finland

e FCBA, InTechFibres Division, CS 90251, F-38044, Grenoble, France

${ }^{\dagger}$ RAGT Energie, zone Innoprod, Chemin de la Teulière, F-81000 Albi, France

g IHE Delft Institute for Water Education, Department of Environmental Engineering and Water Technology, Delft, The Netherlands

*Corresponding author: maria.gonzalez-martinez@outlook.com (M. González Martínez)

\section{Abstract}

Fractionated pyrolysis coupled to gas chromatography and mass spectrometry experiments (Py-GC/MS) were carried out on eight woody and agricultural biomasses, including beech, poplar, pine forest residues, Scot Pine bark, reed canary grass, corn cob, grape seed cake and wheat straw. The selected temperature and duration for each fractionated pyrolysis step allowed separating the volatile pyrolysis products in function of their origin from biomass. As a result, carbohydrate derivatives from hemicelluloses were released at earlier fractionated pyrolysis steps, compared to those produced from cellulose degradation. Phenolic derivatives, mainly produced by lignin, were stepwise produced in function of the length and the nature of their side-chain substituents. Protein derivatives were also released in the whole Py-GC/MS temperature range. Macromolecular composition and biomass family were shown to play a crucial role in the thermal degradation of the biomasses of study. Production profiles exhibited resemblances per chemical species between deciduous and coniferous woods, while they appear to be more heterogeneous for agricultural biomasses. Herbaceous crops showed an intermediate behaviour between woods and agricultural biomasses.

Highlights

- Thermal degradation of eight biomasses was evaluated by fractionated Py-GC/MS.

- Volatile production profiles contribute in biomass structure elucidation.

- Macromolecular composition strongly affects thermal degradation.

- The maximum of carbohydrate derivatives profiles suggests their origin.

- Release order of lignin phenolics were from long to short side-chain. 


\section{Keywords}

- $P y-G C / M S$

- Fractionated pyrolysis

- Lignocellulosic biomass

- Lignin

- Carbohydrates

\section{INTRODUCTION}

Lignocellulosic biomass, including woody, agricultural and herbaceous resources, has been shown to play a strategic role in the current transformation of the energetic production [1]. Its macromolecular composition consists mainly of cellulose, hemicelluloses and lignin, with water, minor amounts of proteins, pectins, minerals and other trace components [2]. While cellulose and hemicelluloses are based on various monosaccharides, lignin is an oxygenated polymer based on phenylpropane units [3]. The proportions and distribution of these macromolecular components in biomass physical structure is complex and dependent on biomass type. Interactions between cellulose, hemicelluloses and lignin in biomass have been demonstrated to play a role in its thermochemical conversion [4-6].

Cellulose is a major structural component of cell walls, which provides mechanical strength and chemical stability to lignocellulosic biomass. It is present in biomass as microfibrils consisting of a semi-crystalline macromolecular structure formed by a long straight chain of (1,4)-D-glucopyranose units linked by $\beta-1,4$ glycosidic bond $[2,7,8]$. Glucan chains composing cellulose are linked together through extensive hydrogen bonding, forming linear organized arrays of chains. The order in the glucan chains in the microfibrils is sometimes altered, leading to disordered areas along the length of microfibrils. These more likely-amorphous regions are suspected to be more propitious to the association of hemicelluloses with cellulose microfibrils [9].

Hemicelluloses are heteropolysaccharides formed by several types of sugar molecules composed either of five or six carbon atoms. In the first case, pentose sugars are the basis of the structure (arabinose, xylose), while in the second case hexose sugars constitute hemicelluloses (galactose, glucose and mannose). Hexuronic acids (e.g. glucuronic acid) can also be present in the structure, as well as acetyl groups connected to the chain, usually to xylans and arabinoxylans [9]. The function of hemicelluloses is to contribute to the formation of a resistant and cohesive network of cellulose microfibrils. The structure of hemicelluloses is conditioned by the main sugar involved in the polymer construction, the frequency and the nature of the ramifications and the degree of polymerization [10].

Lignin structural units are represented by $p$-hydroxypenyl $(H)$, guaiacyl $(G)$ and syringyl $(S)$ units. These units are derived from the copolymerization of $p$-coumaryl alcohol, coniferyl alcohol and sinapyl alcohol, respectively [11]. Important differences exist between lignin structure from hardwood (angiosperm) and softwood (gymnosperm). Lignin from softwood is mostly formed by G-units and some H-units, mainly, while lignin constituting hardwood contains varying ratios of G-and S-units [12]. Lignin in poplar differs from the other hardwoods as it contains p-hydroxybenzoic acid linked to lignin [13]. On the contrary, lignin from herbaceous plants contains three types of units $(H, S$ and $G$ ) [14]. The lignin structure of agricultural biomasses is more complex and contains $\mathrm{G}$-and $\mathrm{H}$-units. In addition, these biomasses often contain $p$-hydroxycinnamic acids ( $p$ - 
coumaric and ferulic acids) [15]. The role of $p$-hydroxycinnamic acids in herbaceous biomasses was described as a bridge between lignin and carbohydrates through LCC (lignin-carbohydrates complexes) [16]. As a result, these acids were not considered as part of the lignin structure. In addition, some proteins can be present in agricultural biomasses $[17,18]$. Lignin function is forming a protective layer for the plant walls by encasing cellulose and hemicellulose of the cell walls [2]. At the same time, covalent bonds between hemicellulose and lignin provide resistance to the structured microfibrillar network of the plant $[19,20]$.

Structurally, significant differences exist between hardwood and softwood in cell structure, concerning complexity and cell types. More precisely, softwoods present a simpler structure with only two cell types which are mainly invariable. Hardwoods are characterized by a higher degree of variability within a higher number of cell types, presenting also a characteristic type of cell (vessel element or pore), which is absent in softwoods [21,22]. In both cases, tissues of woody biomasses contain the main part of lignin in the secondary cell wall layers [23]. Even if the cell structure of agricultural biomasses and herbaceous crops is close to that of hardwood, the main differences concern the macromolecular components forming the cell walls, how they are linked together, and the abundance and nature of pectins, proteins and phenolic compounds [24].

Analytical pyrolysis coupled to gas chromatography and mass spectrometry (Py-GC/MS) has largely been used during the last decades in the elucidation of biomass structure [14,25-28]. This consists of biomass flash heating at rates higher than $10,000 \mathrm{~K} \cdot \mathrm{s}^{-1}$ up to pyrolysis temperatures, typically between 400 to $600{ }^{\circ} \mathrm{C}$. The pyrolysis degradation products, released as volatile species, are then separated, identified and quantified in GC/MS. The production profiles of the released degradation products contribute to explain their origin from macromolecular components in biomass structure. Previous studies including Py-GC/MS simultaneously analyzed a reduced number of biomasses, which were typically from the same biomass family [15,27,29-33]. The use of an optimized temperature and time configuration in fractionated Py-GC/MS experiments was shown to separate pyrolysis products according to their origin from lignin and carbohydrate degradation. At the same time, the yield of pyrolysis products released was shown to be maximized under these conditions and the extent of the secondary in gaseous phase is expected to be minimized [34].

The objective of this work is the broadening of the use of fractionated Py-GC/MS with an optimized temperature and time configuration to the elucidation of the structure of woody and agricultural biomasses, linked to their macromolecular composition. All together eight biomasses were studied. The distribution of the volatile pyrolysis products grouped per chemical family and through the seven steps of the fractionated pyrolysis experiments was firstly studied. In a second step, the formation of volatile pyrolysis products was analysed in function of their repartition in each step of the fractionated Py-GC/MS and in function of the biomass type. Pyrolysis products derived from carbohydrates, lignin and proteins were monitored. Special attention was paid to the correct identification of the source of some degradation products that may be derived from several components, such as $p$-hydroxyphenyl derivatives (protein/lignin/p-hydroxybenzoic acid) and vinyl derivatives (cinnamic acids/lignin). As the aim of the study was to simulate the reactions occurring in thermal processing, samples were analyzed as they were available, without washing, and the role of inorganic components, which was the object of previous studies in the literature [35,36], was not assessed in this case.

\section{MATERIAL AND METHODS}


112 Eight biomasses, representative of the European diversity, were selected for fractionated Py-GC/MS experiments. This includes two deciduous woods (beech, poplar), a coniferous wood (pine forest residues), a coniferous wood bark (Scot pine bark), three agricultural by-products (corn cob, grape seed cake and wheat straw) and one herbaceous crop (reed canary grass).

116 Poplar and beech were harvested by thinning cut in the South of France in the summer 2016. Pine forest residues and Scot pine bark were prepared in Sweden in the summer 2015. Wheat straw was harvested in the South of Sweden in autumn 2015. Finally, corn cob and grape seed cake corresponded to residues collected in October 2015 from seed and oil plants (RAGT, France), which use raw biomasses from the South of France. Woody biomasses were first convectively dried by blowing heated air $\left(40-60^{\circ} \mathrm{C}\right)$ through a perforated floor, until all the material reached about 5\% moisture content (water basis, w.b.). Agricultural biomasses were not dried. All woody and agricultural biomasses, except grape seed cake, were then shredded with a Lindner Micromat 2000 (Linder-Recylingtech $\mathrm{GmbH}$, Spittal, Austria) with $15 \mathrm{~mm}$ screen size. Finally, all biomasses were ground at a particle size inferior to $500 \mu \mathrm{m}$ using a Universal cutting mill Fritsch Pulverisette 19 (Fritsch $\mathrm{GmbH}$, Idar-Oberstein, Germany) with a $0.5 \mathrm{~mm}$ sieve. No pretreatment was applied to remove extractives and inorganic elements (ash) prior to pyrolysis experiments.

127 Biomasses were characterized in terms of macromolecular composition (Table 1) and sugar distribution (Table 128 2) according to methods described previously in [37]. Comments on this characterization are already reported 129 in [38]. Nitrogen content was measured through the Standard XPCEN/TS 15107. Protein content was 130 determined by multiplying nitrogen content by a factor 6.25 , as protein is mainly precipitated in acid hydrolysis 131 together with lignin [17]. Therefore, lignin content was corrected by subtracting with protein content.

132 Table 1. Macromolecular composition of the biomasses

$$
\text { Cellulose Hemicell Lignin Protein Extractives } \underset{\text { (ash) }}{\text { Inorganics }} \underset{\text { Malance }}{\text { Mass }}
$$

Biomass $\%$ wmf $^{*}$

\section{Deciduous wood}

\begin{tabular}{|c|c|c|c|c|c|c|c|}
\hline Beech & 41.3 & 25.3 & 25.2 & 1.3 & 1.9 & 0.8 & 95.7 \\
\hline Poplar & 42.7 & 21.8 & 25.6 & 1.3 & 4.4 & 2.8 & 98.5 \\
\hline \multicolumn{8}{|l|}{ Coniferous wood } \\
\hline Pine forest residues & 22.3 & 27.9 & 23.1 & 4.4 & 18.9 & 2.2 & 98.8 \\
\hline Scot pine bark & 21.9 & 18.3 & 38.2 & 2.5 & 15.2 & 2.8 & 98.9 \\
\hline \multicolumn{8}{|l|}{ Herbaceous crops } \\
\hline Reed canary grass & 39.5 & 25.7 & 20.3 & 4.4 & 6.4 & 6.6 & 102.8 \\
\hline \multicolumn{8}{|c|}{ Agricultural by-products } \\
\hline Corn cob & 38.4 & 34.8 & 13.4 & 2.5 & 6.9 & 1.9 & 97.7 \\
\hline Grape seed cake & 7.8 & 21.9 & 47.2 & 15.6 & 7.6 & 4.2 & 104.2 \\
\hline Wheat straw & 38.1 & 24.7 & 19.3 & 3.1 & 7.8 & 9.3 & 102.3 \\
\hline
\end{tabular}


$* \% w f=$ weight-moisture-free

Table 2. Neutral monosugars distribution and functional groups

\begin{tabular}{|c|c|c|c|c|c|c|}
\hline & \multicolumn{5}{|c|}{ Neutral sugars balance (normalized) } & \multirow{3}{*}{$\begin{array}{c}\begin{array}{c}\text { Functional } \\
\text { groups }\end{array} \\
\text { Acetyl groups } \\
\% \text { wmf }^{\star *} \\
\end{array}$} \\
\hline & Glucose & Xylose & Mannose & Galactose & Arabinose & \\
\hline Biomass & & & $\% *$ & & & \\
\hline \multicolumn{7}{|l|}{ Deciduous wood } \\
\hline Beech & 63.9 & 29.1 & 3.0 & 2.0 & 2.0 & 8.3 \\
\hline Poplar & 68.9 & 22.7 & 4.3 & 2.0 & 2.2 & 5.9 \\
\hline \multicolumn{7}{|l|}{ Coniferous wood } \\
\hline Pine forest residues & 58.8 & 10.7 & 14.4 & 8.7 & 7.5 & 2.7 \\
\hline Scot pine bark & 64.3 & 7.9 & 9.9 & 7.1 & 10.9 & 1.6 \\
\hline \multicolumn{7}{|l|}{ Herbaceous crops } \\
\hline Reed canary grass & 61.0 & 29.9 & 0.4 & 3.1 & 5.6 & 5.0 \\
\hline \multicolumn{7}{|c|}{ Agricultural by-products } \\
\hline Corn cob & 52.4 & 39.4 & 0.0 & 2.5 & 5.7 & 5.0 \\
\hline Grape seed cake & 33.6 & 48.2 & 7.4 & 5.2 & 5.6 & 3.1 \\
\hline Wheat straw & 61.0 & 32.5 & 0.3 & 1.6 & 4.6 & 3.7 \\
\hline
\end{tabular}

$* \%$ of the total monosugars; $* * \% w m=$ weight moisture free

\subsection{PY-GC/MS EXPERIMENTS}

Py-GC/MS measurements were performed with a filament pulse pyrolyzer (Pyrola2000. PyrolAB. Sweden) connected to a gas chromatograph (Agilent 7890B) with a mass spectrometer (Agilent 5977A). A detailed description of the fractionated pyrolysis conditions has been included in a previous work [34]. To sum up, about $100 \mu \mathrm{g}$ of the biomass sample was weighed accurately and placed on the platinum filament in the pyrolyzer sample holder. Each sample was pyrolyzed according to the fractionated pyrolysis program of temperatures and times indicated in Table 3. The most suitable time at each temperature was set in preliminary experiments with beech, by checking that all volatile species are released at each pyrolysis step [34].

Table 3. Time set at each step of fractionated pyrolysis experiments (Py-GC/MS) for the selected temperatures

\begin{tabular}{ccc}
\hline step & temperature $\left({ }^{\circ} \mathbf{C}\right)$ & time $(\mathbf{s})$ \\
\hline 1 & 250 & 40 \\
2 & 300 & 30 \\
3 & 350 & 25 \\
4 & 370 & 20 \\
5 & 400 & 15 \\
\hline
\end{tabular}




\begin{tabular}{lcc}
\hline 6 & 450 & 10 \\
7 & 500 & 5 \\
\hline
\end{tabular}

146 At each pyrolysis temperature, $0.008 \mathrm{~s}$ was the time set to reach a given pyrolysis temperature $(\approx 50,000 \mathrm{~K} \cdot \mathrm{s}$

$\left.147{ }^{1}\right)$. After each step of the fractionated pyrolysis degradation products were swept with helium into the gas

148 chromatography for separation using a mid-polar capillary column (J\&W. DB-1701. $30 \mathrm{~m} \times 0.25 \mathrm{~mm}$. film 1 $149 \mu \mathrm{m})$. After separation, degradation products were detected using a quadrupole mass spectrometry (EI $70 \mathrm{eV})$.

150 Each experiment was carried out twice, which confirmed the repeatability of the results.

151 Table 4 includes volatile species released in fractionated pyrolysis of the eight selected biomasses and 152 detected in GC/MS analysis. Pyrolysis products could be identified thanks to data from the literature [39-42], 153 as well as to the commercial NIST 2011 MS library, by considering a correct identification for a Match/RMatch 154 higher than 900.

155 Table 4. Chemical compounds followed using extracted ion (EI) in GC/MS analysis of the volatile 156 species released in the fractionated pyrolysis of different biomasses

\begin{tabular}{|c|c|c|c|}
\hline Chemical compound & EI & Chemical compound & El \\
\hline Guaiacyls & & Anhydrosugars (and dihydropyranoses) & \\
\hline 3-methylguaiacol & 123 & 1,4-anhydroxylopyranose & 57 \\
\hline guaiacol & 124 & 1,5-anhydroarabinofuranose & 57 \\
\hline homovanillin & 137 & 1,6-anhydroglucopyranose (levoglucosan) & 60 \\
\hline 4-ethylguaiacol & 137 & 1,4-anhydrogalactopyranose & 73 \\
\hline 4-(1-hydroxy-prop-2-enyl)guaiacol & 137 & 1,5-anhydro-4-deoxypent-1-en-3-ulose & 114 \\
\hline 4-methylguaiacol & 138 & 1,4-dideoxy-D-glycero-hex-1-enopyranos-3-ulose & 144 \\
\hline vanillin & 151 & Acids & \\
\hline acetoguaiacone & 151 & acetic acid & 60 \\
\hline eugenol & 164 & Furans & \\
\hline cis-isoeugenol & 164 & $2(5 \mathrm{H})$-furanone & 55 \\
\hline trans-isoeugenol & 164 & 5-hydroxymethyldihydrofuran-2-one & 85 \\
\hline dihydroconiferyl alcohol & 137 & furfural & 96 \\
\hline trans-coniferyl alcohol & 180 & 5-hydroxymethylfurfural & 97 \\
\hline Syringyls & & 2-furanmethanol & 98 \\
\hline syringol & 154 & Ketones & \\
\hline syringylacetone & 167 & hydroxyacetone & 43 \\
\hline 4-ethylsyringol & 167 & 1,2-cyclopentanedione & 98 \\
\hline homosyringaldehyde & 167 & 2-hydroxy-3-methyl-2-cyclopenten-1-one & 112 \\
\hline 4-methylsyringol & 168 & & \\
\hline acetosyringone & 181 & Protein derivatives & \\
\hline syrignaldehyde & 182 & indole & 117 \\
\hline 4-allylsyringol & 194 & methylindole & 130 \\
\hline 4-propenylsyringol & 194 & & \\
\hline p-hydroxyphenyls & & Vinyl derivatives & \\
\hline phenol & 94 & 4-vinylphenol & 120 \\
\hline
\end{tabular}




\begin{tabular}{lr|lr}
\hline 4-methylphenol & 107 & 4-vinylguaiacol & 150 \\
\hline 2-methylphenol & 108 & 4-vinylsyringol & 180 \\
\hline
\end{tabular}

158 Peak areas of pyrolysis products were integrated using extracted-ion chromatogram (EIC) with the selected

159 ion for each compound (Table 4). Then, peak areas were normalized considering the weight of the sample.

160 The average of two parallel measurements was calculated for each point. The estimated standard error for

161 parallel measurements was below $10 \%$. Peak area in the chromatogram was the selected magnitude for the

162 data analysis, due to the impossibility of calibrating all detected chemical species.

163 In a first step, pyrolysis products were grouped per chemical family and their peak areas were added. The 164 production ratio per chemical family at each fractionated pyrolysis step was calculated as a ratio of the total 165 production of volatile species of the given step (Figure 1). The addition of peak areas of different volatile species 166 belonging to the same chemical family can only be considered for comparing trends between families and/or 167 biomasses.

168 Secondly, the production profile of each pyrolysis product was shown versus temperature and step duration.

169 The production of the pyrolysis product was calculated for each step of the fractionated pyrolysis as the 170 percentage of the total production of the given species in the seven steps of fractionated pyrolysis (Figures 2 171 to 10$)$.

\section{RESULTS AND DISCUSSION}

\subsection{ANALYSIS OF THE VOLATILE SPECIES RELEASED PER BIOMASS}

The production of volatile species per chemical family released in the Py-GC/MS experiments with different biomasses was compared (Figure 1). Biomasses were grouped by families: deciduous wood (beech, poplar), coniferous wood and its bark (pine forest residues, Scot pine bark) and agricultural by-products, including herbaceous crops (corn cob, grape seed, cake, reed canary grass, wheat straw).
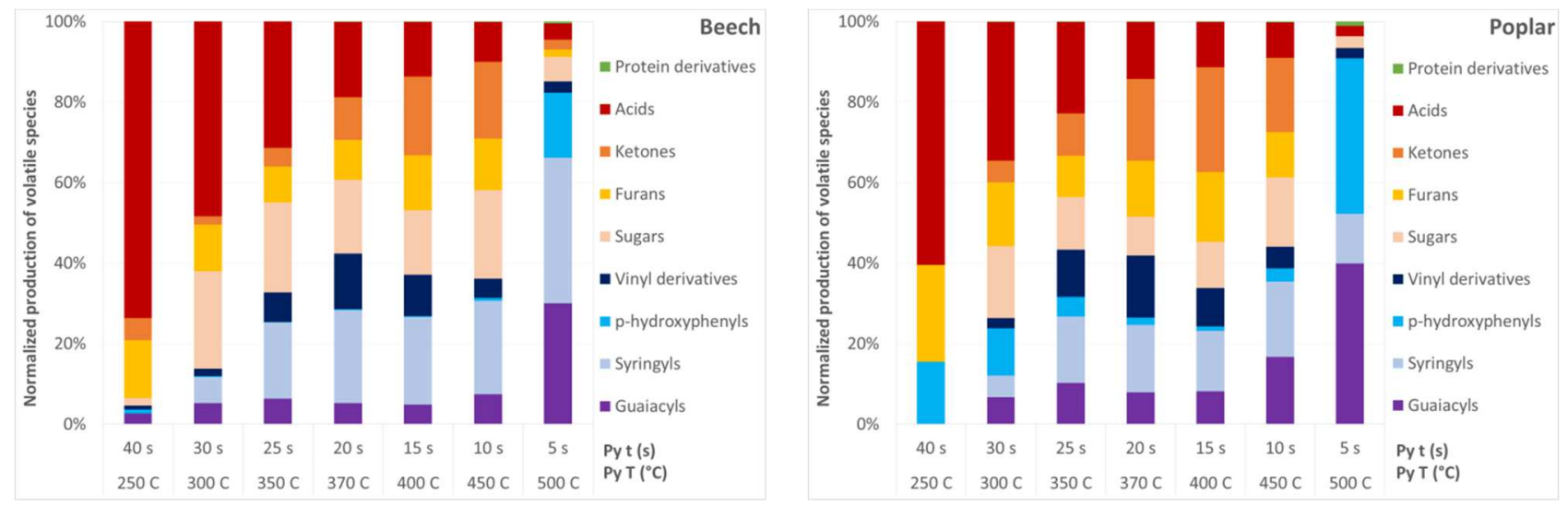

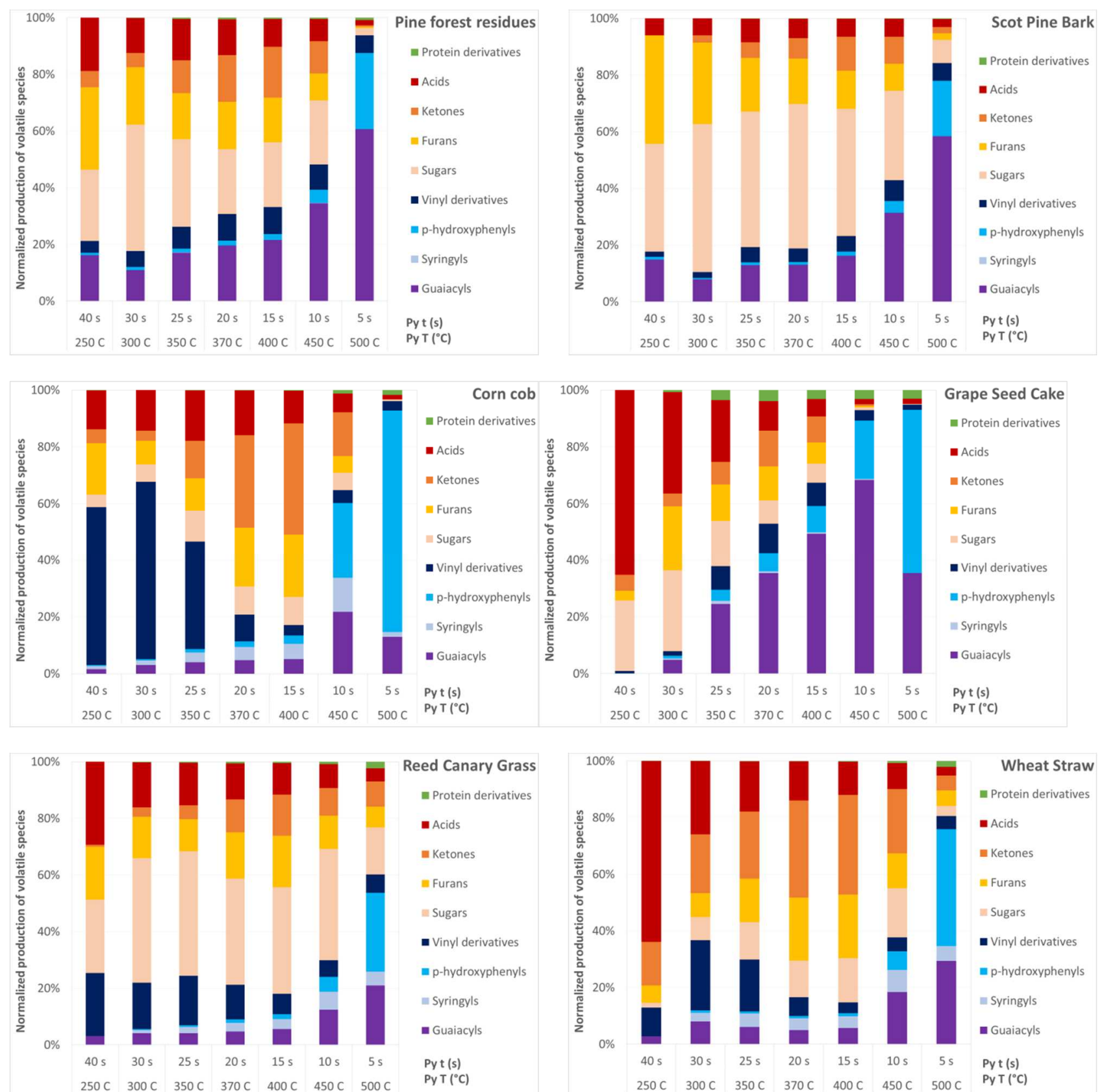

Figure 1. Total production of volatile species classified in chemical families and normalized per temperature in the fractionated fast pyrolysis of the eight selected biomasses in Py-GC/MS

184 The pyrolysis product distribution varied with biomass type and fractionated pyrolysis step. Similar distribution could be observed per duration/temperature step for biomasses from the same family, particularly for deciduous and coniferous wood. This distribution is more heterogeneous for agricultural biomasses, including herbaceous crops, presumably because of their more heterogeneous macromolecular composition compared to woods (Table 1).

189 However, wheat straw, corn cob and reed canary grass showed similarities in product distribution, which is 190 probably due to their rather similar macromolecular structure. These biomasses differed from the woody 191 biomasses and grape seed cake releasing a high proportion of vinyl derivatives in the low temperature region $192\left(250-350^{\circ} \mathrm{C}\right)$. The result indicated the presence of hydroxycinnamates, in which $p$-coumaric acid has been 
reported to acylate the $\gamma$-carbon in lignin side chain and ferulic acids polysaccharides. The ferulic acid has been found to be cross linker forming ether and ester bonds among lignin and carbohydrates, respectively $[16,43]$. Similar to hydroxycinnamic acids, acetic acid and phenol formed from hydroxybenzoic acid in poplar were released in the low temperature region, which reveals that ester bonds are thermally more labile than ether bonds. The release of carbohydrate derivatives (ketones, furans and sugars) slightly varied among agricultural biomasses, indicating differences among macromolecular components. The production of volatile species from grape seed cake is distinct from that of the other agricultural biomasses, which might be due to its noticeably high lignin content, as well as differences in lignin units. However, similarities were found among coniferous woods, which are enriched with guiacyl type lignin, the lignin type also predominant in grape seed cake.

\subsection{DETAILED ANALYSIS OF VOLATILE SPECIES PER DETECTED CHEMICAL COMPOUND}

Volatile species detected in each fractionated Py-GC/MS experiment were classified in chemical families in function of their nature into phenolic, carbohydrate and protein derivatives. The production profiles of each volatile species, represented by the normalized peak area in function of the step of the fractionated pyrolysis, were compared for the eight biomasses (Figures 2 to 10).

\subsubsection{Phenolic derivatives}

Phenol production (Figure 2) occurred in the whole fractionated pyrolysis range and was characterized by two relative maxima, except for poplar, with a single maximum at $350^{\circ} \mathrm{C}$, representing half of its phenol production. Poplar contains lignin linked p-hydroxybenzoic acid that in pyrolysis is converted to simple phenol.. Methylphenols were characterized by an enhanced production with pyrolysis temperature, with a minor maximum at $350^{\circ} \mathrm{C}$. It has been reported in the literature that phenols released in the temperature range of 400-600 $\stackrel{\circ}{\mathrm{C}}$ might be produced in secondary reactions from lignin, via demethoxylation of guaicyl type lignin derivatives [44]. Phenolic derivatives were released at significantly higher temperatures compared to the corresponding guaiacyl and syringyl counterparts, which might confirm the secondary reaction phenomenon. However, by using an optimized duration for each temperature step of the fractionated Py-GC/MS, the yield of volatile species is expected to be maximized and secondary reactions are expected to be minimized [34]. Therefore the origin of these $p$-hydroxyphenyl derivatives could be mainly attributed to $\mathrm{H}$-type lignin units. Other minor routes of formation might also be involved, as for phenol, 2-methylphenol and 4-methylphenol, which can be produced from lignin or the aminoacid tyrosine in proteins [45]. 

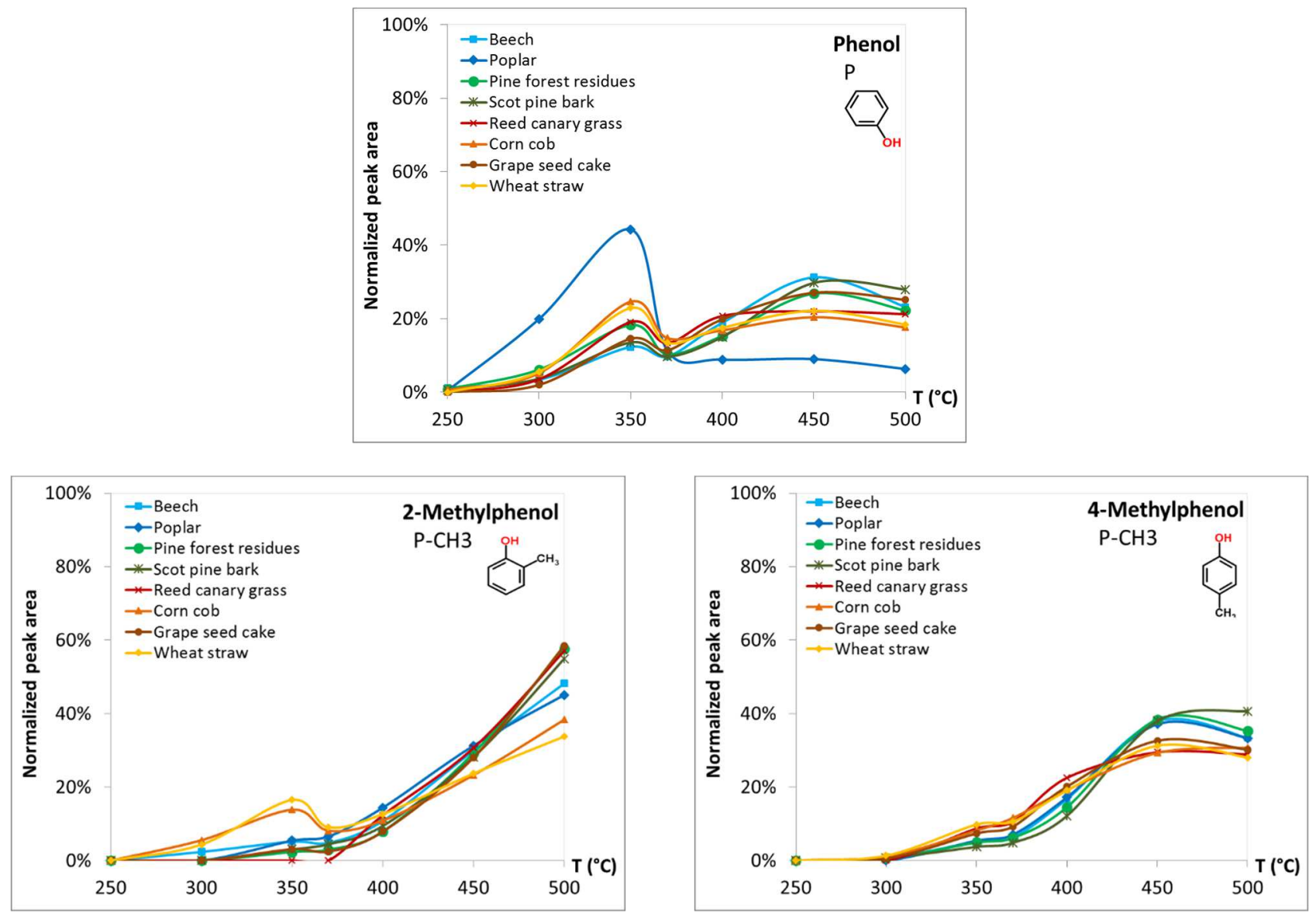

Figure 2. Profiles of production of phenyl- derivatives of eight biomasses in fractionated Py-GC/MS

Equivalent guaiacyl- and syringyl- derived structures with the same side chain length were compared so as to assess if the production routes of phenolic compounds with similar structure might be close (Figures 3 and 4).

For guaiacyl- and syringyl- compounds with short side chains (Figure 3), the maximum of production is between 350 and $370^{\circ} \mathrm{C}$ for agricultural biomasses (wheat straw and corn cob) and around $450^{\circ} \mathrm{C}$ for woody biomasses (beech, poplar, forest residues, pine bark). The exception of this behaviour is for 4-methylguaiacol and 4methylsyringol, which present the maximum of production for all biomasses at around 400 to $450{ }^{\circ} \mathrm{C}$. The appearance of several maxima in the production profile of 4-methylguaiacol and 4-methylsyringol in comparison to the other linear saturated side chain structures indicates that these degradation products might be formed from different routes [46].

234 By comparing biomass behaviour per families, similarities could be observed for woody biomasses, which showed production maxima mainly from 400 to $450{ }^{\circ} \mathrm{C}$ (Figure 3). On the contrary, the production of these compounds by corn cob and wheat straw occurred in the whole fractionated pyrolysis temperature range, with a production maximum from 300 to $400{ }^{\circ} \mathrm{C}$ depending on the product. Reed canary grass exhibited an intermediate behaviour between woody and agricultural biomasses. Grape seed cake showed a particular behaviour which does not correspond between equivalent guaiacyl- and syringyl- derivatives. Indeed, while the maximum of its guaiacol production profile is at around $450^{\circ} \mathrm{C}$, the corresponding maximum for the syringol production is at around $350^{\circ} \mathrm{C}$. Concerning methyl- and ethyl- guaiacyl- derivatives, grape seed cake behaviour is closer to that of woods, which is not the case for the equivalent syringyl derivatives. Furthermore, only few 
syringyl type degradation products were detected, whose thermal behaviour was different in comparison to the 244 corresponding guaiacyl derivatives.
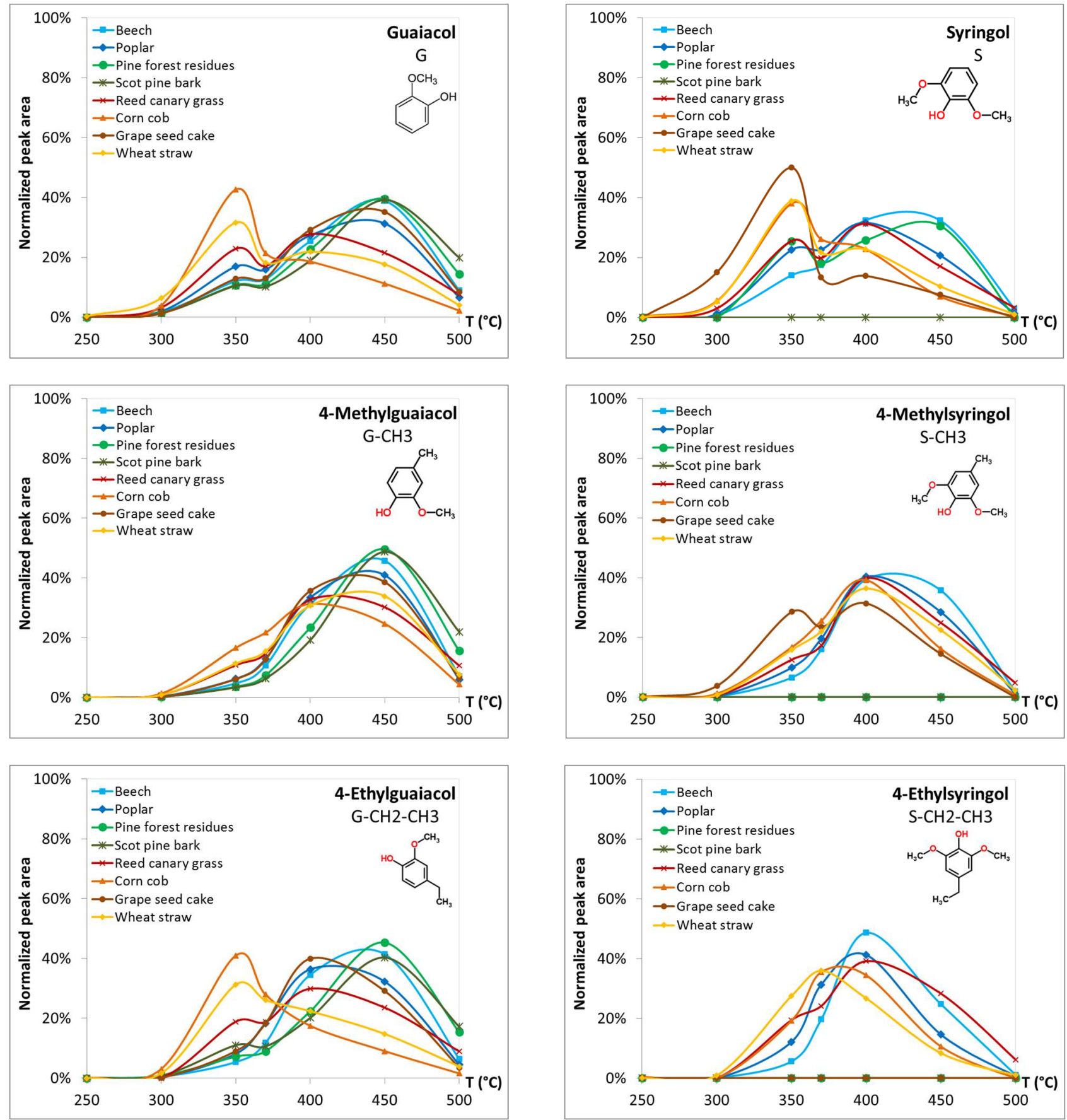

Figure 3. Profiles of production of analogous short chain guaiacyl- (left) and syringyl-(right) derivatives of eight biomasses in fractionated Py-GC/MS

250 In the case of guaiacyl- and syringyl- compounds with unsaturated and/or oxygenated side-chains (Figure 4),

251 the maximum of their production was generally at lower temperatures, around $350{ }^{\circ} \mathrm{C}$, for all biomasses. This maximum was especially marked for grape seed cake, which presented a high lignin content, and reed canary grass. The formation of all of these compounds continued at higher temperatures, but the yield was much lower. A second local maximum at higher temperature (around $400^{\circ} \mathrm{C}$ ) could be observed for the production of both guaiacyl- and syringyl compounds from all biomasses, indicating a probable different origin for the 
same degradation products.

257 The patterns observed for the formation of most of the degradation products in Figure 4 were very similar for 258 all biomasses, for both the G- and S-series. This may indicate that these products are directly originated from 259 lignin, as a result of the cleavage of $\beta$-O-4 linkage of lignin [44]. Surprising behaviour could be noticed in the 260 case of vanillin, acetoguaiacone and transconiferyl alcohol (only in the G-series) for corn cob, reed canary 261 grass and wheat straw. This was probably caused by one or several unknown parallel degradation routes.

262 Dihydroconiferyl alcohol was released in a significantly high amount already at $300^{\circ} \mathrm{C}$ from pine forest residue 263 and scot pine bark. The formation of this compound at low temperatures might be related to the high extractive 264 content of these biomasses. This hypothesis is supported by the fact that this alcohol has been detected in the monomer form in coniferous wood extractives [47].
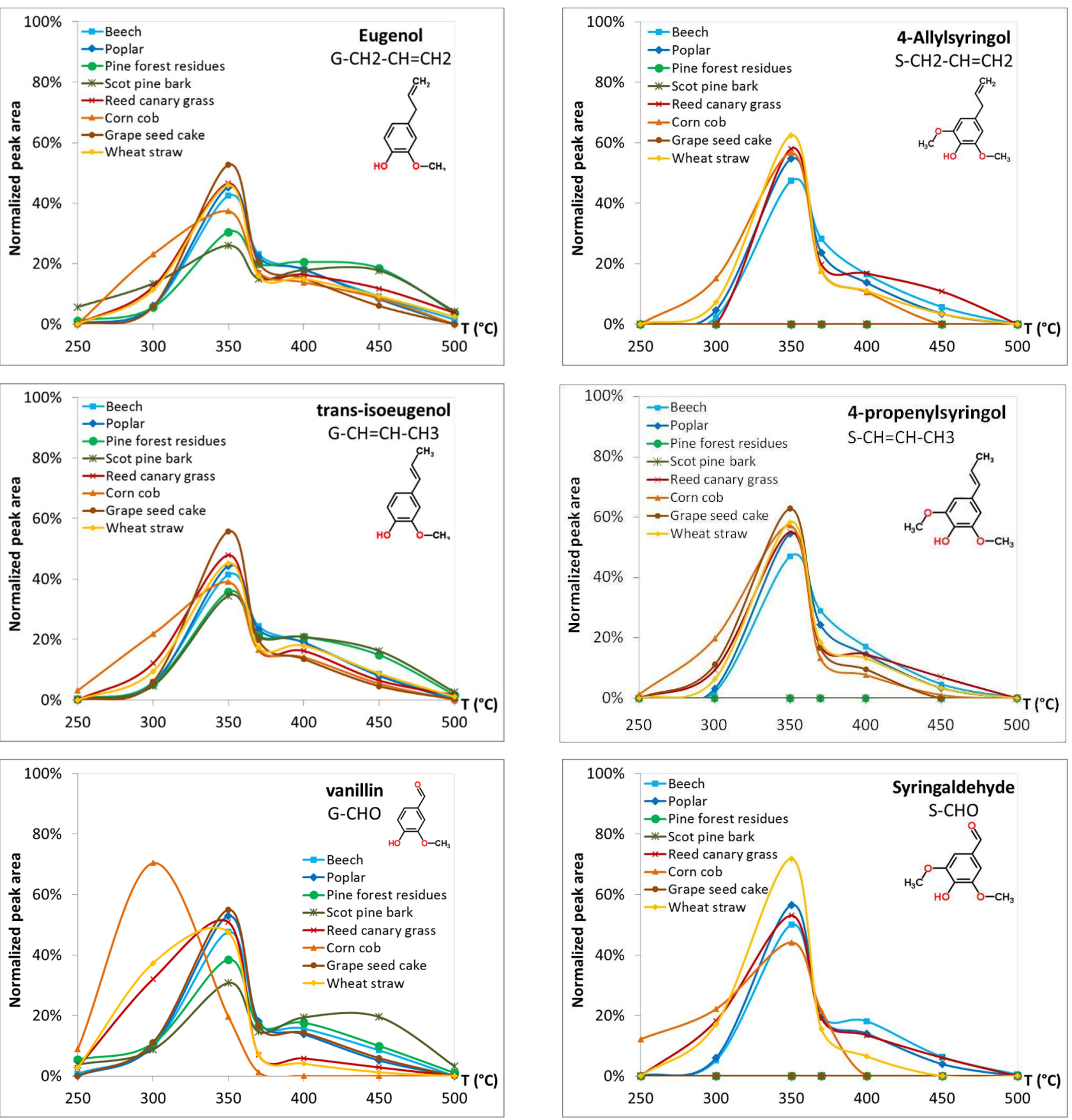

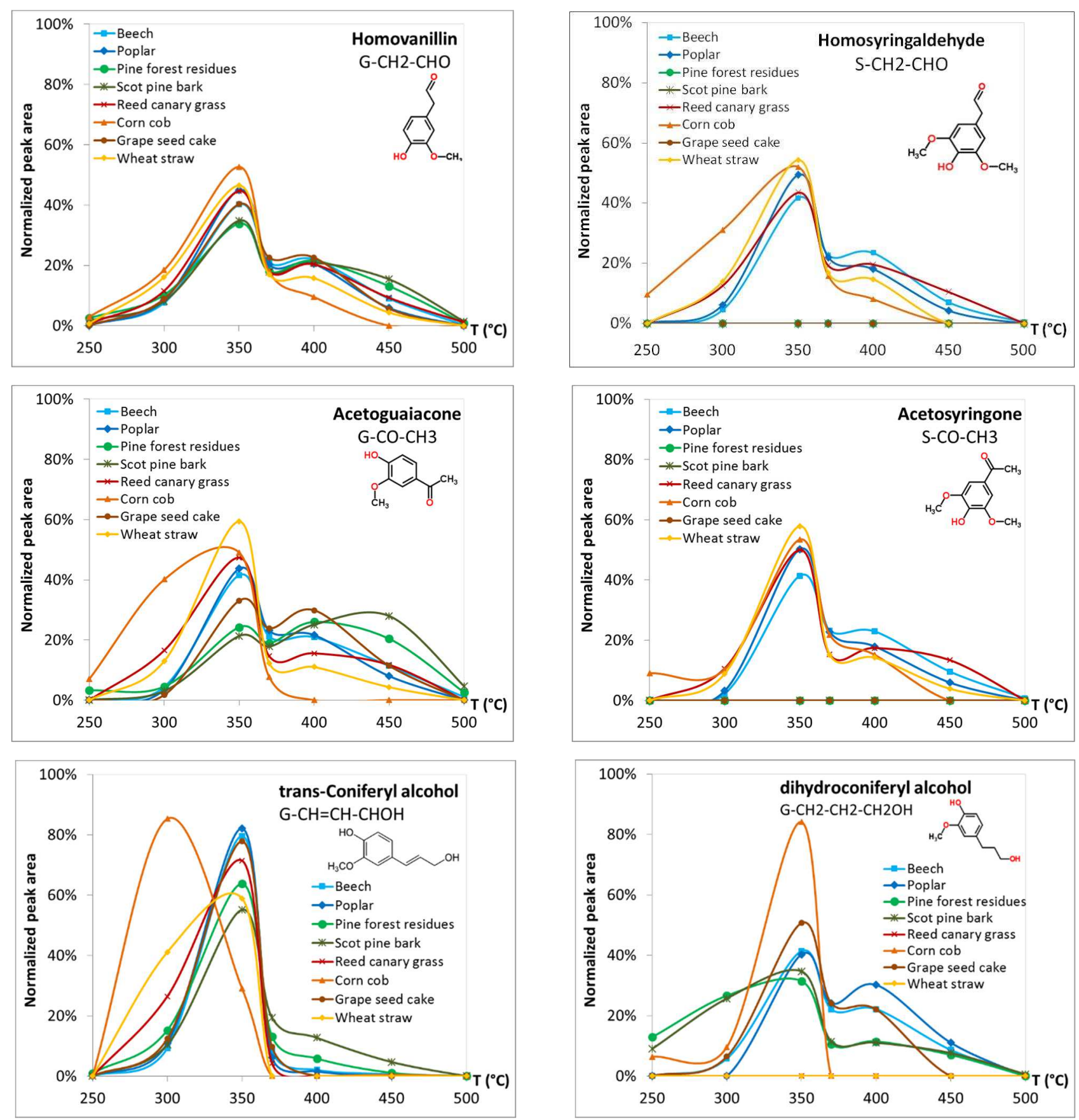

Figure 4. Profiles of production of unsaturated and oxygenated guaiacyl- (left) and syringyl-(right) derivatives of eight biomasses in fractionated Py-GC/MS

274 For herbaceous and agricultural biomasses, vinylphenol and vinylguaiacol can be also formed from $p$ 275 hydroxycinnamic acids ( $p$-coumarylic and ferulic acids) in addition to lignin [15,48]. According to [34], the first 276 maximum of production of these compounds could correspond to the production from $p$-hydroxycinnamic 277 acids, while the maximum at higher temperatures could represent the formation of this compound from lignin. 278 In the case of wheat straw, corn cob and reed canary grass, the maximum of the production for 4-vinylguaiacol was at around $350^{\circ} \mathrm{C}$, which could indicate that the major part of the production of this compound is derived 280 from $p$-hydroxycinnamic acids. In the case of woody biomasses, the maximum was at intermediate and higher 281 temperatures. For grape seed cake (high content in lignin) and reed canary grass (herbaceous crop), the 
behaviour was intermediate (Figure 5).
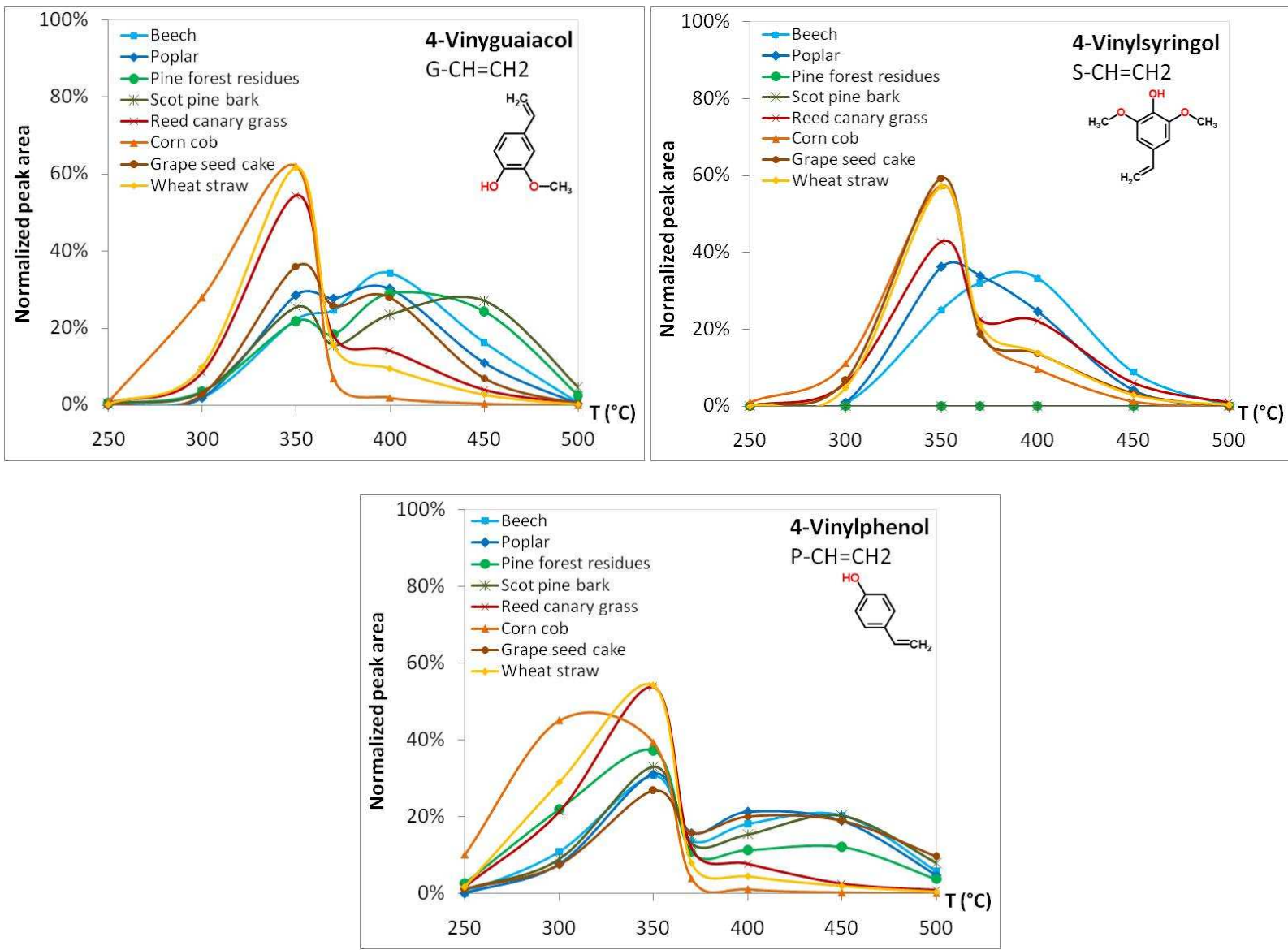

Figure 5. Profiles of production of vinyl derivatives of eight biomasses in fractionated Py-GC/MS

\subsubsection{Carbohydrate derivatives}

Six carbohydrate-derived molecules were identified in the volatile mixture resulting from the Py-GC/MS experiments of 8 biomasses (Figure 6). The production of these molecules was reported to be directly related to the thermal decomposition of cellulose and hemicelluloses in biomass $[45,49]$. Hemicelluloses are an amorphous heteropolymer, which is thermally decomposed at low pyrolysis temperatures (250 to $320{ }^{\circ} \mathrm{C}$ ) [50,51]. Cellulose is a more crystalline polymer that degrades at slightly higher temperatures (around 280 to $400{ }^{\circ} \mathrm{C}$ ) [51-53]. The origin of the sugar molecules released can therefore be associated to their origin in function of their maximum temperature of production. As a result, hemicelluloses derivatives would be 1,4anhydroxylopyranose and 1,5-anhydro-4-deoxypent-1-en-ulose (derived from xylan), 1,5anhydroarabinofuranose (derived from arabinan) [23], 1,4-anhydrogalactopyranose (derived from galactan), since their maximum temperature of production was between 300 and $350{ }^{\circ} \mathrm{C}$, which corresponds to the temperature range of hemicelluloses degradation. On the contrary, 1,6-anhydroglucopyranose (levoglucosan) would be derived from cellulose, as its maximum of production was at around $400{ }^{\circ} \mathrm{C}$ for annual plants and $450 \stackrel{\circ}{ } \mathrm{C}$ for woods. Finally, the production profile of 1,4-dideoxy-D-glycero-hex-1-enopyranos-3-ulose occurred at lower temperatures for grape seed cake and softwood $\left(350^{\circ} \mathrm{C}\right)$, and at higher temperatures for agricultural biomass, herbaceous crops and hardwood. This compound is formed from cellulose- and hexose-sugar-based 
hemicelluloses, such as galactoglucomannan and glucomannan. Its profile of production, compared to those of 1,4-galactopyranose and 1,6-anhydroglucopyranose, suggests that the first maximum would mainly correspond to the degradation of hexose-sugar-based hemicelluloses and the second maximum could be attributable to cellulose. This behaviour might be in agreement with biomass sugar composition (Table 2), as a higher mannose and galactose content was measured for grape seed cake and softwood, including bark , while the cellulose content is higher for deciduous wood and agricultural biomasses ( 38.1 to $42.7 \%$, compared to 7.8 to $22.3 \%)$.
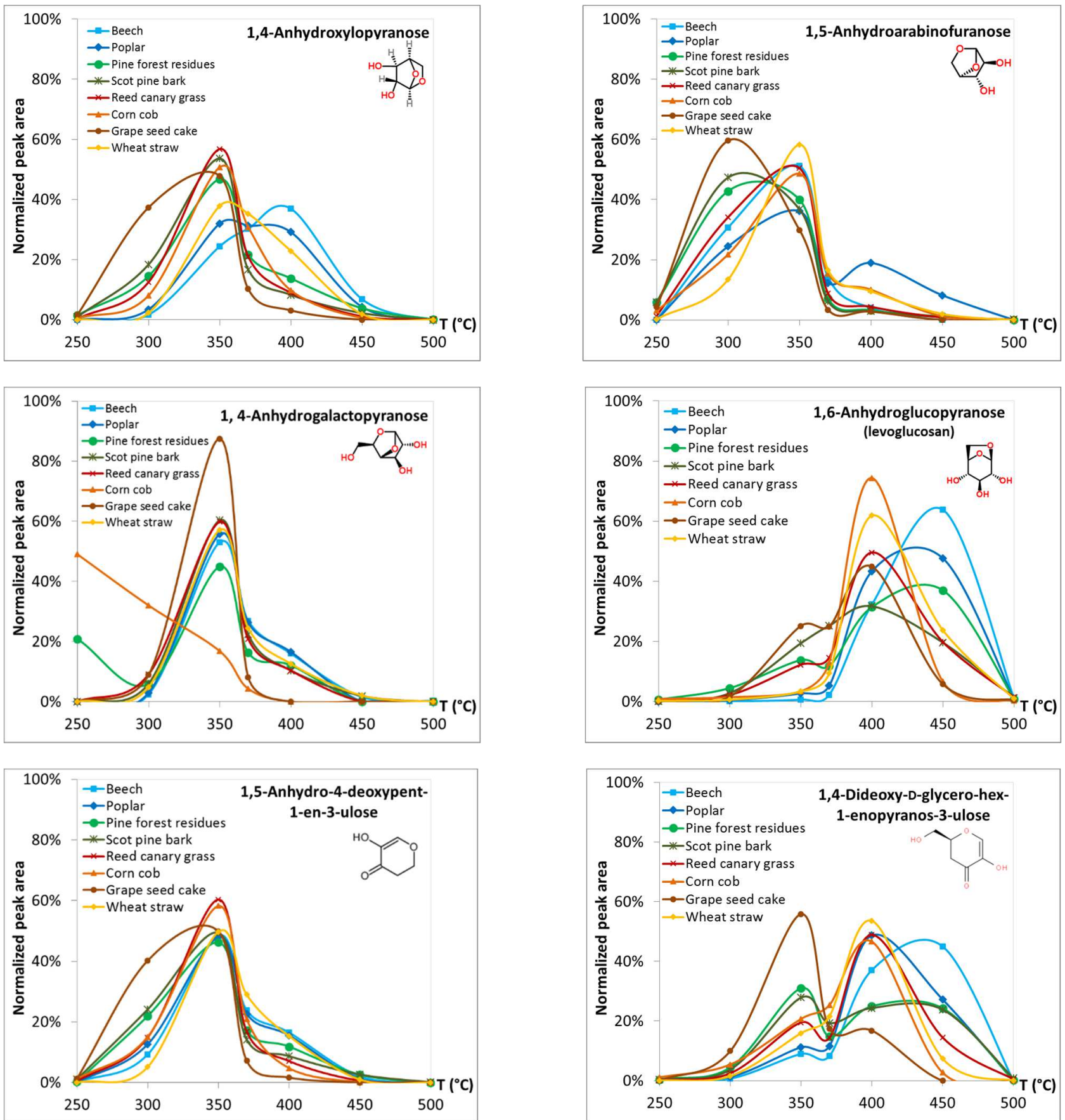

Figure 6. Profiles of production of sugar molecules of eight biomasses in fractionated Py-GC/MS

313 Small molecules, including acids, ketones and furans, are principally carbohydrate derivatives. Acetic acid is one of the major detected compounds in fractionated Py-GC/MS of biomass (Figure 7). Its profile of formation, 
similar for all the biomasses in this study, is characterized by a maximum of production at $350{ }^{\circ} \mathrm{C}$, followed by a regular production until $450^{\circ} \mathrm{C}$. The main mechanism of formation of acetic acid is from the scission of acetyl groups in hemicelluloses [54], which is accordance with the maximum of production at lower temperatures in

$318 \mathrm{Py}$-GC/MS. In addition to hemicelluloses, in some herbaceous plants the $\gamma$-carbon in lignin side chain has been reported to be acetylated and is susceptible to release acetic acid [15]. However, this release of acetic acid from lignin side chain is expected to occur in the same temperature region as from hemicelluloses, due to the ester linkage, but in a lower amount. Other mechanisms have been proposed, as the decomposition of uronic acid unit in hemicelluloses and through the complex reaction of ring-opened sugar units [55,56], which could correspond to the regular production at intermediate temperatures in Py-GC/MS. The differences in acetyl content in the biomasses studied (from 1.6 to $8.3 \%$ ) do not allow to distinguish a higher production of acetic acid in Figure 7, as the percentages of the total production per pyrolysis step are represented.

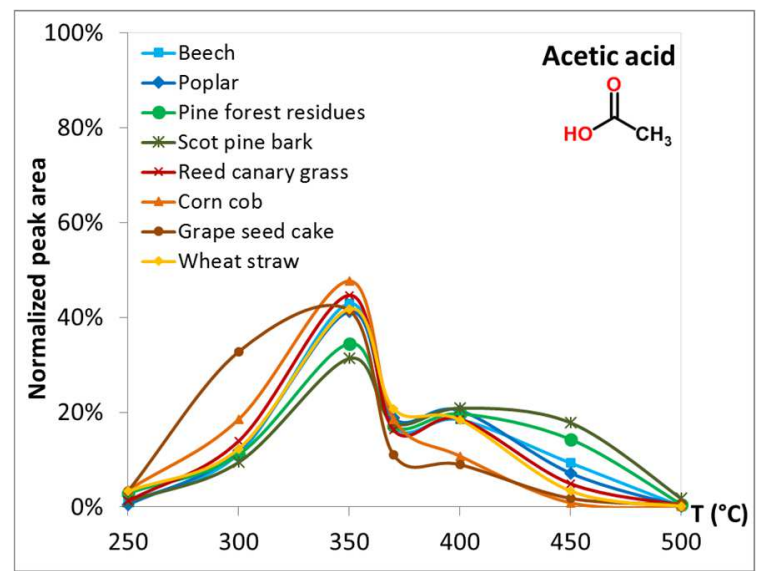

Figure 7. Profile of production of acetic acid of eight biomasses in fractionated Py-GC/MS

One linear ketone (hydroxyacetone) and two cyclic ketones (1,2-cyclopentanedione and 2-cyclopenten-1-one, 2-hydroxy-3-methyl-) were identified in the experiments (Figure 8). Ketones and other small compounds were reported to be released in the rapid depolymerization of hemicelluloses, but also from cellulose [57], directly or through unstable intermediaries which go through dehydration, fragmentation and secondary reactions [58]. Cyclic ketones are produced in hemicelluloses depolymerization $[5,59,60]$, derived from pyran or furan rings [58], but also in cellulose pyrolysis at high temperatures $[57,61,62]$. These pathways of formation might be in accordance with the highest percentage of production at the intermediate steps of the fractionated pyrolysis, without any clearly observable maximum temperature. Noteworthy is the exception of beech, which exhibited increasing production until $400{ }^{\circ} \mathrm{C}$, suggesting the presence of some parallel formation routes of this 

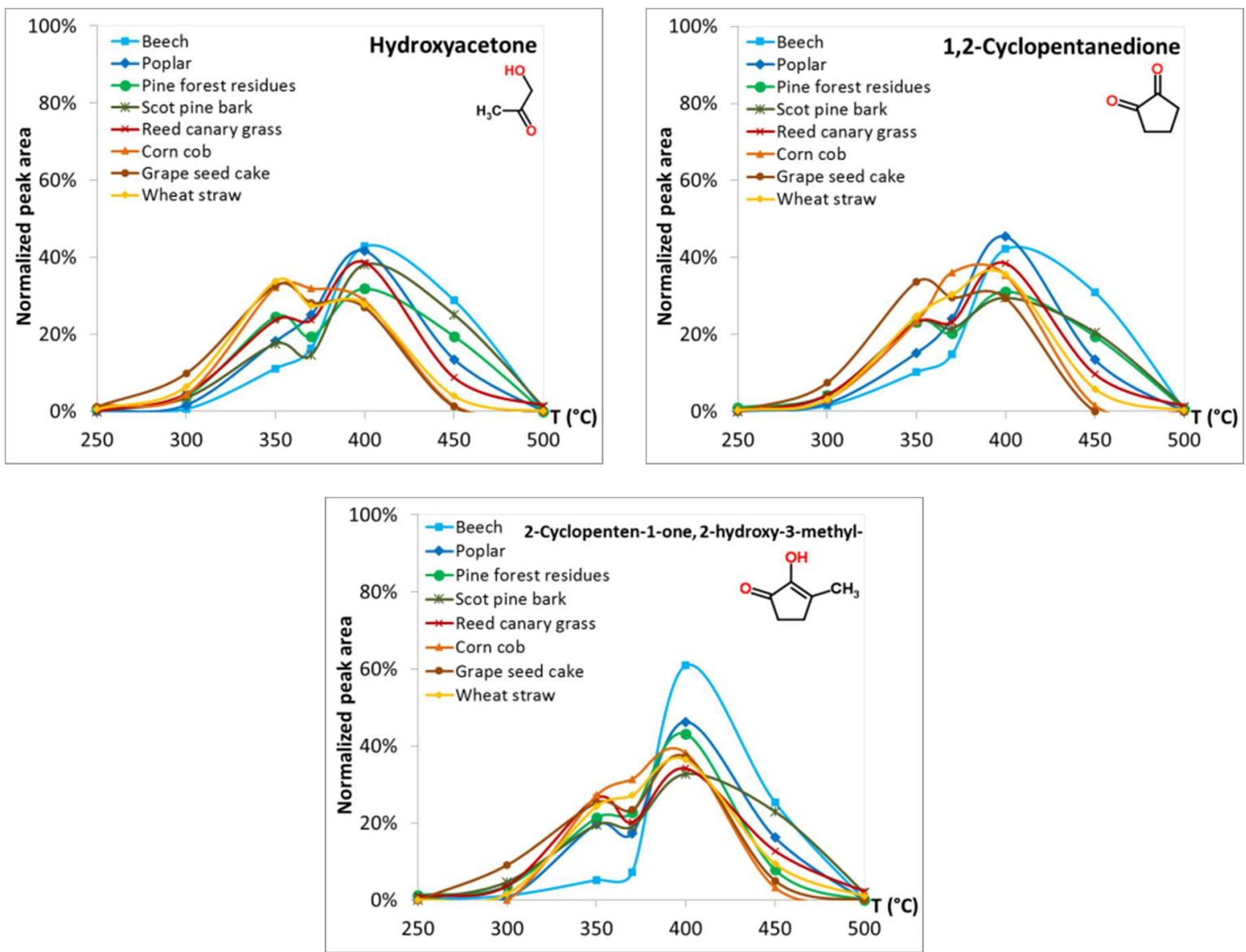

340 Figure 8. Profiles of production of ketones of eight biomasses in fractionated Py-GC/MS

341 Furans were in general produced at intermediate to high temperatures under the established Py-GC/MS

342 operating conditions (Figure 9). Furfural constituted an exception, since it was produced mainly around 350

$343{ }^{\circ} \mathrm{C}$, with a small peak at $400^{\circ} \mathrm{C}$. The origin of furans in the thermal decomposition of cellulose was pointed out

344 as depolymerization reactions. They consist in a contraction of the pyran ring of levoglucosan through the

345 elimination of oxygenated groups and the formation of double bonds $(\mathrm{C}=\mathrm{C})$ could end in a furan ring in cellulose

346 char. Then, weak bonds might break and liberate furan compounds such as furfural [63]. The release of furfural

347 from hemicelluloses is attributed to the ring-opening and rearrangement reactions of the xylan unit [59], which

348 might occur at lower temperatures than the formation of this product from cellulose. In general, furan production

349 from hemicelluloses is related to depolymerization reactions occurring by cleavage of glycosidic linkages

350 between sugar units. This formation typically happens at temperatures slightly higher for glucomannan-based

351 hemicelluloses, compared to xylan-based hemicelluloses [60], as pyran rings derived from glucomannan (6

352 C-atoms) can change into more stable furan rings (5 C-atoms) [58]. The two relative maxima observed in the

353 production curves of furans might contribute to explain the percentage of the production of each pyrolysis

354 compound derived from hemicelluloses or from cellulose, respectively, as hemicelluloses thermal degradation

355 starts at lower temperatures. Most of the furfural production may be derived from hemicelluloses, as the

356 maximum of the curve is at around $350^{\circ} \mathrm{C}$, or even at lower temperature for grape seed cake and coniferous

357 wood. Deciduous wood and reed canary grass showed a maximum of production at around $400{ }^{\circ} \mathrm{C}$ for the

358 other furans detected. They might therefore come from cellulose, or from hemicelluloses [64], either less

359 accessible or linked to cellulose. 

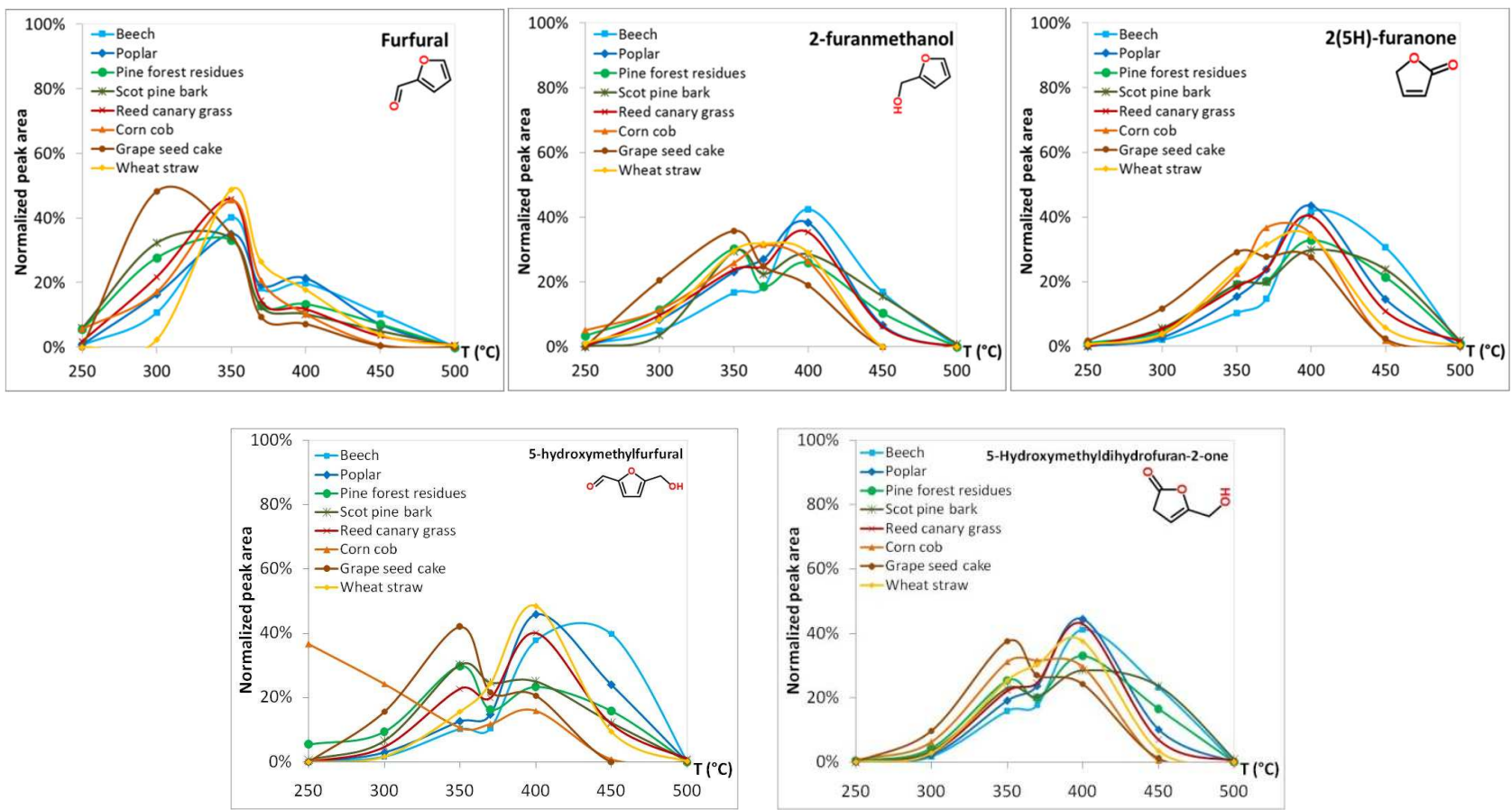

Figure 9. Profiles of production of furans of eight biomasses in fractionated Py-GC/MS

Indole and methylindole, which were reported to be derived from protein thermal degradation [57,58], are produced in the whole range of fractionated pyrolysis (Figure 10). Their production profiles are different from those of phenol, 2-methylphenol and 4-methylphenol, which were reported to be partially produced by proteins [45].This confirms that these phenol derivatives have also other sources than proteins.

The fact that the specific marker compounds (the indoles) for proteins were detected in all biomasses is an indication of the high sensitivity of the applied analysis method, as the protein content is extremely low, especially in the woody biomasses.
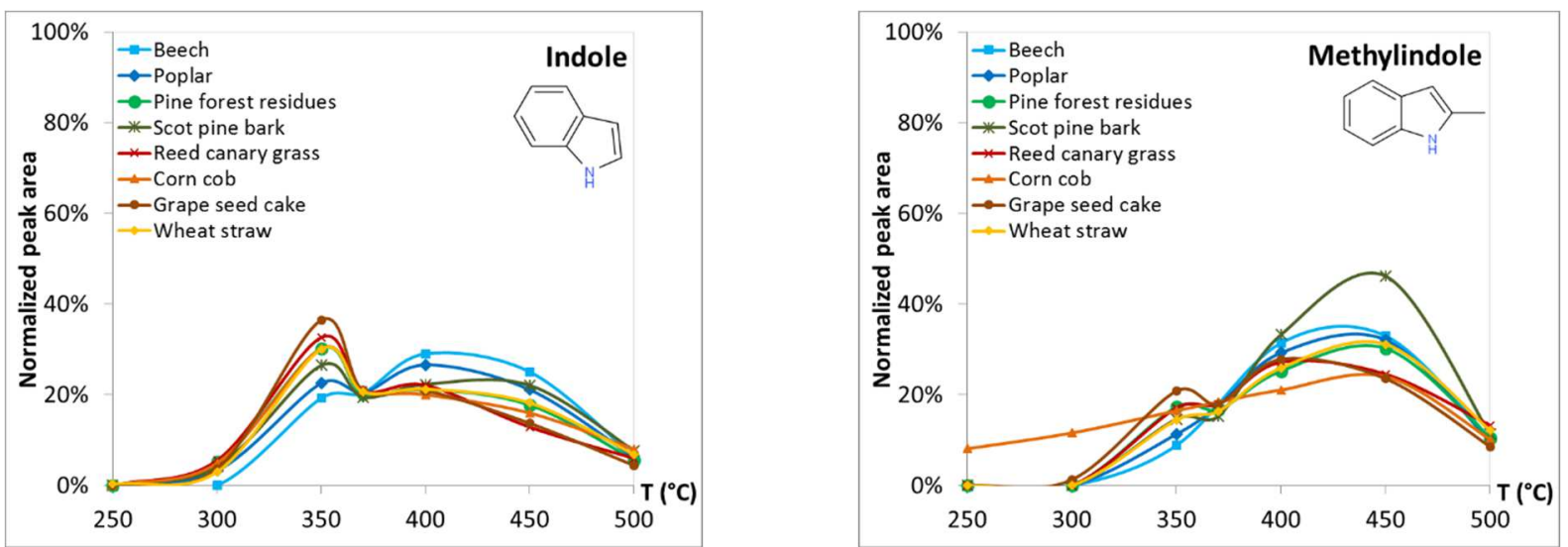

Figure 10. Profiles of production of protein derivatives of eight biomasses in fractionated Py-GC/MS 
volatile products from the macromolecular components of biomass, namely cellulose, hemicelluloses and lignin. Important differences could be observed in the distribution of the pyrolysis volatile products in function of the biomass type. In particular, deciduous wood, represented by beech and poplar, exhibited similar behaviours in terms of volatile species release. This was also showed for coniferous wood, represented by pine forest residues and Scot pine bark. On the contrary, agricultural biomasses showed strong differences in the distribution of the pyrolysis products along the temperature/duration pyrolysis program. These differences may be due to the more heterogeneous macromolecular composition of agricultural biomasses, particularly noticeable between corn cob, which presents a high polysaccharide content, and grape seed cake, with a high lignin content.

The percentages of each pyrolysis product produced per temperature/duration step of the pyrolysis program, compared to the total production of the volatile species, were shown to contribute to distinguish the origin of the pyrolysis products from cellulose, hemicelluloses and lignin. In the case of phenyl derivatives, guaiacyls and syringyls with longer side chain substituents were produced at lower pyrolysis temperatures, while phenolic compounds without side chain, such as guaiacol and syringol, were released at higher temperatures. This indicates a more difficult removal of these last compounds from the biomass structure in thermal degradation, compared to the long-chain phenolic compounds that are expected to be released from easily cleaved aryl ether structures. Furthermore, the structure of hardwood and softwood might be more resistant to thermal degradation, compared to agricultural biomasses, according to the production profiles of lignin derivatives. In the case of polysaccharides, pyrolysis products exhibiting a maximum in the production profile at low to intermediate pyrolysis temperatures (around $350^{\circ} \mathrm{C}$ ) might be mainly derived from hemicelluloses. On the contrary, those presenting a maximum at intermediate to high pyrolysis temperatures (around $400{ }^{\circ} \mathrm{C}$ ) would be derived from cellulose or from less accessible hemicelluloses.

\section{ACKNOWLEDGMENTS}

This project has received funding from the European Union's Horizon 2020 research and innovation program under grant agreement No 637020-MOBILE FLIP. The Université Fédérale de Toulouse Midi-Pyrénées (France), CEA Grenoble (France) and VTT Finland are also acknowledged for the support of this work.

\section{REFERENCES}

[1] European Commission, State of play on the sustainability of solid and gaseous biomass used for electricity, heating and cooling in the EU, 2014. https://ec.europa.eu/energy/sites/ener/files/2014_biomass_state_of_play_.pdf (accessed September 28, 2016).

[2] P.F.H. Harmsen, W.J.J. Huijgen, L.M. Bermúdez López, R.R.C. Bakker, Literature Review of Physical and Chemical Pretreatment Processes for Lignocellulosic Biomass, Energy Research Centre of the Netherlands, 2010.

[3] S.V. Pisupati, A.H. Tchapda, Chapter 15: Thermochemical Processing of biomass, in: Adv. Bioprocess Technol., Pogaku Ravindra, Switzerland, 2015.

[4] T. Hosoya, H. Kawamoto, S. Saka, Cellulose-hemicellulose and cellulose-lignin interactions in wood pyrolysis at gasification temperature, J. Anal. Appl. Pyrolysis. 80 (2007) 118-125. doi:10.1016/j.jaap.2007.01.006. 
[5] S.D. Stefanidis, K.G. Kalogiannis, E.F. Iliopoulou, C.M. Michailof, P.A. Pilavachi, A.A. Lappas, A study of lignocellulosic biomass pyrolysis via the pyrolysis of cellulose, hemicellulose and lignin, J. Anal. Appl. Pyrolysis. 105 (2014) 143-150. doi:10.1016/j.jaap.2013.10.013.

[6] T. Kan, V. Strezov, T.J. Evans, Lignocellulosic biomass pyrolysis: A review of product properties and effects of pyrolysis parameters, Renew. Sustain. Energy Rev. 57 (2016) 1126-1140. doi:10.1016/j.rser.2015.12.185.

[7] S.K. Guha, H. Kobayashi, A. Fukuoka, Chapter 13: Conversion of cellulose to sugar, in: Chapter 13Conversion Cellul. Sugars, 2010. http://pubs.rsc.org/en/content/chapter/bk978184973035800344/978-1-84973-035-8 (accessed March 24, 2016).

[8] A. Dufresne, Les nanotechnologies dans l'industrie papetière, Tech. Ing. (2010).

[9] L.D. Gomez, C.G. Steele-King, S.J. McQueen-Mason, Sustainable liquid biofuels from biomass: the writing's on the walls, New Phytol. 178 (2008) 473-485. doi:10.1111/j.1469-8137.2008.02422.x.

[10] H.V. Scheller, P. Ulvskov, Hemicelluloses, Annu. Rev. Plant Biol. 61 (2010) 263-289. doi:10.1146/annurev-arplant-042809-112315.

[11] B. Monties, Les polymères végetaux: les lignines, 1980.

[12] Kirk-Othmer, Encyclopedia of Chemical Technology, Willey, http://onlinelibrary.wiley.com/book/10.1002/0471238961/homepage/EditorsContributors.html (accessed March 22, 2016).

[13] K. Morreel, J. Ralph, H. Kim, F. Lu, G. Goeminne, S. Ralph, E. Messens, W. Boerjan, Profiling of Oligolignols Reveals Monolignol Coupling Conditions in Lignifying Poplar Xylem, Plant Physiol. 136 (2004) 3537-3549. doi:10.1104/pp.104.049304.

[14] A. Sequeiros, J. Labidi, Characterization and determination of the S/G ratio via Py-GC/MS of agricultural and industrial residues, Ind. Crops Prod. 97 (2017) 469-476. doi:10.1016/j.indcrop.2016.12.056.

[15] J.C. del Río, A. Gutiérrez, I.M. Rodríguez, D. Ibarra, Á.T. Martínez, Composition of non-woody plant lignins and cinnamic acids by Py-GC/MS, Py/TMAH and FT-IR, J. Anal. Appl. Pyrolysis. 79 (2007) 3946. doi:10.1016/j.jaap.2006.09.003.

[16] J. Ralph, Hydroxycinnamates in lignification, Phytochem. Rev. 9 (2010) 65-83. doi:10.1007/s11101009-9141-9.

[17] Y.W. Sari, U. Syafitri, J.P.M. Sanders, M.E. Bruins, How biomass composition determines protein extractability, Ind. Crops Prod. 70 (2015) 125-133. doi:10.1016/j.indcrop.2015.03.020.

[18] C. Dupont, S. Rougé, A. Berthelot, D. Da Silva Perez, A. Graffin, F. Labalette, C. Laboubée, J.-C. Mithouard, S. Pitocchi, Bioenergy II: Suitability of Wood Chips and Various Biomass Types for Use in Plant of BtL Production by Gasification, Int. J. Chem. React. Eng. 8 (2010). doi:10.2202/15426580.1949 .

[19] J.J. Harrington, R. Booker, Astley R.J., Modelling the elastic properties of softwood. Part I: The cellwall lamellae, Holz Als Roh- Werkst. (1998) 37-41.

[20] E. Sjöström, Wood chemistry: Fundamentals and Applications, 2nd ed., Academic Press, 1993.

[21] USDA, Wood handbook: wood as an engineering material - US Department of Agriculture, 2010.

[22] J.-L. Faulon, G.A. Carlson, P.G. Hatcher, A three-dimensional model for lignocellulose from gymnospermous wood, Org. Geochem. 21 (1994) 1169-1179. doi:10.1016/0146-6380(94)90161-9.

[23] K. Werner, L. Pommer, M. Broström, Thermal decomposition of hemicelluloses, J. Anal. Appl. Pyrolysis. 110 (2014) 130-137. doi:10.1016/j.jaap.2014.08.013.

[24] J. Vogel, Unique aspects of the grass cell wall, Curr. Opin. Plant Biol. 11 (2008) 301-307. doi:10.1016/j.pbi.2008.03.002. 
[25] M. Mattonai, D. Licursi, C. Antonetti, A.M. Raspolli Galletti, E. Ribechini, Py-GC/MS and HPLC-DAD characterization of hazelnut shell and cuticle: Insights into possible re-evaluation of waste biomass, J. Anal. Appl. Pyrolysis. (2017). doi:10.1016/j.jaap.2017.07.019.

[26] T. Ohra-aho, F.J.B. Gomes, J.L. Colodette, T. Tamminen, S/G ratio and lignin structure among Eucalyptus hybrids determined by Py-GC/MS and nitrobenzene oxidation, J. Anal. Appl. Pyrolysis. 101 (2013) 166-171. doi:10.1016/j.jaap.2013.01.015.

[27] J. Zhao, W. Xiuwen, J. Hu, Q. Liu, D. Shen, R. Xiao, Thermal degradation of softwood lignin and hardwood lignin by TG-FTIR and Py-GC/MS, Polym. Degrad. Stab. 108 (2014) 133-138. doi:10.1016/j.polymdegradstab.2014.06.006.

[28] J. Rencoret, J.C. del Río, K.G.J. Nierop, A. Gutiérrez, J. Ralph, Rapid Py-GC/MS assessment of the structural alterations of lignins in genetically modified plants, J. Anal. Appl. Pyrolysis. 121 (2016) 155164. doi:10.1016/j.jaap.2016.07.016.

[29] L.C.A. Barbosa, C.R.A. Maltha, V.L. Silva, J.L. Colodette, Determination of the siringyl/guaiacyl ratio in eucalyptus wood by pyrolysis-gas chroma-tography/mass spectrometry (PY-GC/MS), Quím. Nova. 31 (2008) 2035-2041. doi:10.1590/S0100-40422008000800023.

[30] C.F. Lima, L.C.A. Barbosa, C.R. Marcelo, F.O. Silvério, J.L. Colodette, Comparison between analytical pyrolysis and nitrobenzene oxidation for determination of syringyl/guaiacyl ratio in Eucalyptus spp. lignin, BioResources. 3 (2008) 701-712. doi:10.15376/biores.3.3.701-712.

[31] L. Chen, X. Wang, H. Yang, Q. Lu, D. Li, Q. Yang, H. Chen, Study on pyrolysis behaviors of non-woody lignins with TG-FTIR and Py-GC/MS, J. Anal. Appl. Pyrolysis. 113 (2015) 499-507. doi:10.1016/j.jaap.2015.03.018.

[32] T. Ohra-aho, F.J.B. Gomes, J.L. Colodette, T. Tamminen, Carbohydrate composition in Eucalyptus wood and pulps - Comparison between Py-GC/MS and acid hydrolysis, J. Anal. Appl. Pyrolysis. 129 (2018) 215-220. doi:10.1016/j.jaap.2017.11.010.

[33] A.O. Balogun, O.A. Lasode, A.G. McDonald, Thermochemical and pyrolytic analyses of Musa spp. residues from the rainforest belt of Nigeria, Environ. Prog. Sustain. Energy. 37 (2018) 1932-1941. doi:10.1002/ep.12869.

[34] M. González Martínez, T. Ohra-aho, D. da Silva Perez, T. Tamminen, C. Dupont, Influence of step duration in fractionated Py-GC/MS of lignocellulosic biomass, J. Anal. Appl. Pyrolysis. 137 (2019) 195202. doi:10.1016/j.jaap.2018.11.026.

[35] P.R. Patwardhan, J.A. Satrio, R.C. Brown, B.H. Shanks, Influence of inorganic salts on the primary pyrolysis products of cellulose, Bioresour. Technol. 101 (2010) 4646-4655. doi:10.1016/j.biortech.2010.01.112.

[36] M. Kleen, G. Gellerstedt, Influence of inorganic species on the formation of polysaccharide and lignin degradation products in the analytical pyrolysis of pulps, J. Anal. Appl. Pyrolysis. 35 (1995) 15-41. doi:10.1016/0165-2370(95)00893-J.

[37] S. Jacob, D. Da Silva Perez, C. Dupont, J.-M. Commandré, F. Broust, A. Carriau, D. Sacco, Short rotation forestry feedstock: Influence of particle size segregation on biomass properties, Fuel. 111 (2013) 820 828. doi:10.1016/j.fuel.2013.04.043.

[38] M. González Martínez, C. Dupont, S. Thiéry, X.-M. Meyer, C. Gourdon, Impact of biomass diversity on torrefaction: Study of solid conversion and volatile species formation through an innovative TGAGC/MS apparatus, Biomass Bioenergy. 119 (2018) 43-53. doi:10.1016/j.biombioe.2018.09.002.

[39] O. Faix, D. Meier, I. Fortlann, Thermal degradation products of wood. Gas chromatographic separation and mass spectrometric characterization of lignin derived products, Holz Als Roh- Werkst. (1990) 281285.

[40] O. Faix, D. Meier, I. Fortlann, Thermal degradation products of wood. A collection of electron-impact (EI) mass spectra of monomeric lignin derived products, Holz Als Roh- Werkst. (1990) 351-354. 
[41] O. Faix, I. Fortlann, J. Bremer, D. Meier, Thermal degradation products of wood. Gas chromatographic separation and mass spectrometric characterization of polysaccharide derived products, Holz Als RohWerkst. (1991) 213-219.

[42] O. Faix, D. Meier, I. Fortlann, J. Bremer, Thermal degradation products of wood. A collection of electron-impact (EI) mass spectra of monomeric polysaccharide derived products, Holz Als Roh- Werkst. (1991) 299-304.

[43] C. Crestini, D.S. Argyropoulos, Structural Analysis of Wheat Straw Lignin by Quantitative 31P and 2D NMR Spectroscopy. The Occurrence of Ester Bonds and $\alpha-\mathrm{O}-4$ Substructures, J. Agric. Food Chem. 45 (1997) 1212-1219. doi:10.1021/jf960568k.

[44] H. Kawamoto, Lignin pyrolysis reactions, J. Wood Sci. 63 (2017) 117-132. doi:10.1007/s10086-0161606-z.

[45] G.C. Galletti, P. Bocchini, Pyrolysis/gas chromatography/mass spectrometry of lignocellulose, Rapid Commun. Mass Spectrom. 9 (1995) 815-826. doi:10.1002/rcm.1290090920.

[46] K. Kuroda, A. Nakagawa-izumi, Analytical pyrolysis of lignin: Products stemming from $\beta-5$ substructures, Org. Geochem. 37 (2006) 665-673. doi:10.1016/j.orggeochem.2006.01.012.

[47] D. Fengel, G. Wegener, W. De Gruyer, Wood-chemistry, ultrastructure, reactions, Berlin and New York, 1984.

[48] T.B.T. Lam, K. Kadoya, K. Iiyama, Bonding of hydroxycinnamic acids to lignin: ferulic and p-coumaric acids are predominantly linked at the benzyl position of lignin, not the $\beta$-position, in grass cell walls, Phytochemistry. 57 (2001) 987-992. doi:10.1016/S0031-9422(01)00052-8.

[49] V. Becerra, J. Odermatt, M. Nopens, Identification and classification of glucose-based polysaccharides by applying Py-GC/MS and SIMCA, J. Anal. Appl. Pyrolysis. 103 (2013) 42-51. doi:10.1016/j.jaap.2012.12.018.

[50] M.J. Prins, K.J. Ptasinski, F.J.J.G. Janssen, Torrefaction of wood: Part 1. Weight loss kinetics, J. Anal. Appl. Pyrolysis. 77 (2006) 28-34. doi:10.1016/j.jaap.2006.01.002.

[51] P.T. Williams, S. Besler, The influence of temperature and heating rate on the slow pyrolysis of biomass, Renew. Energy. 7 (1996) 233-250. doi:10.1016/0960-1481(96)00006-7.

[52] W.-H. Chen, J. Peng, X.T. Bi, A state-of-the-art review of biomass torrefaction, densification and applications, Renew. Sustain. Energy Rev. 44 (2015) 847-866. doi:10.1016/j.rser.2014.12.039.

[53] E. Biagini, F. Barontini, L. Tognotti, Devolatilization of Biomass Fuels and Biomass Components Studied by TG/FTIR Technique, Ind. Eng. Chem. Res. 45 (2006) 4486-4493. doi:10.1021/ie0514049.

[54] D.K. Shen, S. Gu, A.V. Bridgwater, The thermal performance of the polysaccharides extracted from hardwood: Cellulose and hemicellulose, Carbohydr. Polym. 82 (2010) 39-45. doi:10.1016/j.carbpol.2010.04.018.

[55] S. Wang, B. Ru, H. Lin, Z. Luo, Degradation mechanism of monosaccharides and xylan under pyrolytic conditions with theoretic modeling on the energy profiles, Bioresour. Technol. 143 (2013) 378-383. doi:10.1016/j.biortech.2013.06.026.

[56] S. Wang, B. Ru, H. Lin, W. Sun, Pyrolysis behaviors of four O-acetyl-preserved hemicelluloses isolated from hardwoods and softwoods, Fuel. 150 (2015) 243-251. doi:10.1016/j.fuel.2015.02.045.

[57] M.S. Mettler, A.D. Paulsen, D.G. Vlachos, P.J. Dauenhauer, Pyrolytic conversion of cellulose to fuels: levoglucosan deoxygenation via elimination and cyclization within molten biomass, Energy Environ. Sci. 5 (2012) 7864-7868. doi:10.1039/C2EE21305B.

[58] F.-X. Collard, J. Blin, A review on pyrolysis of biomass constituents: Mechanisms and composition of the products obtained from the conversion of cellulose, hemicelluloses and lignin, Renew. Sustain. Energy Rev. 38 (2014) 594-608. doi:10.1016/j.rser.2014.06.013. 
[59] D.K. Shen, S. Gu, A.V. Bridgwater, Study on the pyrolytic behaviour of xylan-based hemicellulose using TG-FTIR and Py-GC-FTIR, J. Anal. Appl. Pyrolysis. 87 (2010) 199-206. doi:10.1016/j.jaap.2009.12.001.

[60] C. Branca, C.D. Blasi, C. Mango, I. Hrablay, Products and Kinetics of Glucomannan Pyrolysis, (2013). doi:10.1021/ie400155x.

[61] Y. Wu, Z. Zhao, H. Li, F. He, Low temperature pyrolysis characteristics of major components of biomass, J. Fuel Chem. Technol. 37 (2009) 427-432. doi:10.1016/S1872-5813(10)60002-3.

[62] M. S. Mettler, S. H. Mushrif, A. D. Paulsen, A. D. Javadekar, D. G. Vlachos， P. J. Dauenhauer, Revealing pyrolysis chemistry for biofuels production: Conversion of cellulose to furans and small oxygenates, Energy Environ. Sci. 5 (2012) 5414-5424. doi:10.1039/C1EE02743C.

[63] S. Wang, X. Guo, T. Liang, Y. Zhou, Z. Luo, Mechanism research on cellulose pyrolysis by Py-GC/MS and subsequent density functional theory studies, Bioresour. Technol. 104 (2012) 722-728. doi:10.1016/j.biortech.2011.10.078.

[64] S. Wang, Z. Xia, Q. Wang, Z. He, H. Li, Mechanism research on the pyrolysis of seaweed polysaccharides by Py-GC/MS and subsequent density functional theory studies, J. Anal. Appl. Pyrolysis. 126 (2017) 118-131. doi:10.1016/j.jaap.2017.06.018.

[65] M. Kleen, T. Ohra-aho, T. Tamminen, On the interaction of HBT with pulp lignin during mediated laccase delignification—a study using fractionated pyrolysis-GC/MS, J. Anal. Appl. Pyrolysis. 70 (2003) 589-600. doi:10.1016/S0165-2370(03)00028-7.

[66] J. Rencoret, P. Prinsen, A. Gutiérrez, Á.T. Martínez, J.C. del Río, Isolation and Structural Characterization of the Milled Wood Lignin, Dioxane Lignin, and Cellulolytic Lignin Preparations from Brewer's Spent Grain, J. Agric. Food Chem. 63 (2015) 603-613. doi:10.1021/jf505808c. 